\title{
Religiously Diverse Multicultural Literature for Early Childhood
}

\author{
Susan V. Bennett ${ }^{1}$ (D) AnnMarie Alberton Gunn ${ }^{1} \cdot$ Kaya van Beynen $^{1} \cdot$ Mary Lou Morton $^{2}$
}

Accepted: 20 March 2021 / Published online: 21 April 2021

(C) The Author(s), under exclusive licence to Springer Nature B.V. 2021

\begin{abstract}
Through culturally sustaining teaching, teachers can transform practice and pedagogy to challenge inequities and create a space for affirming students' diverse religious backgrounds. Teacher educators and teachers must develop this pedagogy to understand diverse student populations and facilitate students becoming citizens who accept and empathize with others who have different religious beliefs and traditions. Our purpose was to explore and select multicultural literature that represents religious diversity for early childhood classrooms. Our search focused on major religions practiced in the U.S., which yielded 549 books. We obtained 436 books; 54 met the rubric criteria with a majority focusing on Judaism. We identified four themes: immigration and refugees, holidays, sharing memories and stories, building understandings and empathy. We offered examples of the themes and an example of implementation in the classroom. We recommended this sample that we believe can foster understanding and respect for diverse religious and cultural groups.
\end{abstract}

Keywords Religion $\cdot$ Early childhood $\cdot$ Multicultural literature $\cdot$ Culturally sustaining pedagogy

\section{Introduction}

Religion has been a major influence on society and socialization of citizens, whether positive or negative. Religious and secular values might positively impact families and children's lives who are in early childhood classrooms. Unfortunately, religious intolerance and hatred continue to prevail across the globe. During the civil rights movement, churches were burned and bombed; more recently, congregations of synagogues, churches, and mosques around the world have been victims of shootings, bombings, and arson. The FBI (2017) reported $22.1 \%$ of reported hate crimes in the U.S. were instigated based on religion, second to 58.1

Susan V. Bennett

sbennet3@usf.edu

AnnMarie Alberton Gunn

gunn@usf.edu

Kaya van Beynen

kayatown@usf.edu

Mary Lou Morton

marylou.morton@mail.waldenu.edu

1 University of South Florida, 140 7th Avenue South, St. Petersburg, Florida 33701, USA

2 Walden University Minneapolis, 100 Washington Ave. South, Suite 900, Minneapolis, Minnesota 55401, USA
$\%$ motivated by a race/ethnicity/ancestry bias. Hate crimes motivated by religion continue to rise, yet the United Nations General Assembly "adopted, without a vote, the Declaration on the Rights of Persons Belonging to National or Ethnic, Religious and Linguistic Minorities," (U.N. Commission on Human Rights, 1996, para. 1). It clearly stated, "the promotion and protection of the rights of persons belonging to national or ethnic, religious and linguistic minorities contribute to political and social stability and peace and enrich the cultural heritage of society as a whole," (U.N. Commission on Human Rights, 1996, para. 8).

Immigration often brings diverse cultures and religions; schools reflect this change. Although the largest movement in the U.S. has been an increase in non-religious belief, interfaith marriages present another dynamic in schools, which may be present in early childhood classrooms. The PEW Religion and Public Life Report revealed people who have "married since 2000 are about twice as likely to be in religious intermarriages as are people who got married before 1960" (PEW forum, 2015). Multicultural education can promote more enlightened beliefs about diverse religions, therefore, possibly contribute to fewer hate crimes.

Many scholars in multicultural education have called for classroom teachers and teacher educators to embrace culturally sustaining pedagogy (CSP) due to growth of diverse students globally and in the U.S. (Paris, 2012; Ladson-Billings, 
2014; Vass, 2017). "Culturally sustaining pedagogy seeks to perpetuate and foster-to sustain-linguistic, literate, and cultural pluralism as part of the democratic project of schooling" (Paris, 2012, p. 95); cultural identity is not stagnant but constantly changing and shifting. With the ongoing inflow globally of diverse populations coupled with unrest across the world, it is essential teachers and teacher educators no longer ignore the significance of citizenship or CSP (Banks, 2004). Teacher educators and teachers must develop CSP not only to understand diverse student populations, but to facilitate students becoming citizens who accept and empathize with others who have different beliefs and traditions.

U.S. schools and teachers face challenges of academic freedom due to mandated high-stakes tests and policies often resulting in academic subjects, such as social studies, being marginalized through decreased instructional time (Fitchett et al., 2014). In U.S. schools, religion is often avoided and considered uncomfortable or too controversial to discuss. Religious beliefs and practices influence how people live; religion plays a significant role in many people's lives (Douglass, 2002). Because U.S. schools are rooted in American and Christian epistemologies, students who embrace or come from religions other than mainstream Christianity "face difficulties in negotiating everyday school practices" (Subedi, 2006, p. 227). As the world's diversity increases and considering current sociopolitical climates, it is especially imperative teachers renegotiate how to talk about religion. Peyton and Jalongo (2008) shared how legal separation of church and state may distance these discussions in schools; yet, with children's literature, teachers can "model respectful behavior and enhance understanding of a variety of faiths" (p. 302). Through multicultural literature, teachers can enact CSP and facilitate conversations with children to talk about diverse religions, as the children develop cross-cultural understandings. Therefore, we explored multicultural children's literature for authenticity to stimulate discussions about religious diversity for teachers, students, and teacher educators.

\section{Religion Around the World}

While certain religions dominate in different areas of the world (i.e., Christianity in Europe, Islam in Central Asia, Hinduism in India), all religions are dispersed throughout the world, and this religious mix exists at international, national and regional levels (Jacobs, 2019). This diversified mosaic of religions has impacted schools throughout the world.

Considerable migration occurred in Finland recently, and the five largest groups of immigrants came from Estonia $(33,855)$, Russia (29.590), Sweden (8557), Somalia (7393), and China (6000) (Niemi et al. 2014). Researchers interviewed nine academic teachers, a special education teacher, a study advisor, and social worker at a secondary school to examine how teachers may use school celebrations to provide greater inclusion for immigrant populations. They also observed two special holidays: Independence Day and Christmas. Although teachers demonstrated awareness that celebrations often had religious overtones and conformed to ideas of Finnishness, researchers concluded teachers did not include ways to connect to non-Finnish students. The school focused on 'multicultural theme' days, which potentially perpetuates stereotypes and emphasizes the 'otherness.' Teachers conveyed learning Finish traditions might make students feel like they belong, but, in actuality, resulted in students standing out as different and 'the other.' This similar notion can be described as 'tacos and egg rolls' or 'holidays around the world,' where teachers create multicultural lessons centering around food and celebrations, a superficial understanding of different cultures (Rothenberg, 2000; Evans \& Gunn, 2011; Bennett et al., 2017). The study demonstrates instead of increasing inclusion, it highlighted differences.

Many immigrants crossed into Greece and changed schools' demographics. Greek school curricula incorporate Orthodox Christian religious education within primary and secondary schools. Karamouzis (2015) investigated 1009 student teachers and 432 in-service teachers through a questionnaire to find their religious education views. Although teachers are required to include a specific religion in instruction, the majority suggested an interreligious education course might help to diminish animosity toward others with different beliefs and cultures. Karamouzis (2015) added teachers thought interreligious courses could facilitate students becoming "free and critically thinking" individuals (p. 179). Notably, Karamouzis reported both groups affirmed a democratic country must present as a non-specific religious public entity.

The Netherlands tried a variety of systems to accommodate the increase in minority groups. Dutch society constructed schools as state and secular or private and Christian. These two groups polarized, whereby each group had distinct freedom to develop its own social departments, such as trade unions and political parties, the goal to live in peace (Ter Avest \& Wingerden, 2017). With an influx of Islamic residents, the Dutch faced the challenge of providing for different Islamic practices, and differences among Islamic cultures left Islamic immigrants with the need to build their own social networks. School leaders worried separation could result in formation of radical Islamic groups, and nine Islamic schools developed to meld Dutch social expectations and Islamic practices. They made progress in cultivating greater respect among diverse groups by highlighting shared 
values among Islamic groups, Christians, and secular Dutch society.

\section{Religion in the U.S.}

While the range of religions practiced in the U.S. is larger than many countries around the world (Adherents, 2001), Christianity dominates as the largest religion in the country, encompassing $70.6 \%$ of the population (Pew Research Center, 2014). Table 1 includes a list of the most widely practiced religions in the U.S.

Christian affiliation is in decline while non-Christian religious affiliation is increasing, especially among Muslims and Hindus (Lipka, 2015). Most notably are the rise of Americans who report being unaffiliated with any religion (Lipka, 2015). Based on many changes in society, public school educators need to have enhanced understandings related to religion and the ways in which this knowledge can inform best practices for the classroom.

\section{Christian Privilege}

In the U.S., religion has been a debated topic with a long history of previous influence in education. Schools, originally rooted in religion, began with values of earliest colonization, White and Protestant (Marshall, 2006), For example, Native Americans were forced into boarding schools, and Christianity imposed on them to erase beliefs, traditions, and culture. Creationism and evolution still cause debates for curricula development. These two examples illustrate the complexity of religion in schools' history, and many more exist. Christianity has been and remains a major influence in the U.S., and public-school practices incorporate Christian practices (Blumenfeld, 2006). It is possible mainstream Christianity continues to dominate schools.

Table 1 American religious identity survey

\begin{tabular}{ll}
\hline Religion & \% of population \\
\hline Christianity & 71 \\
Nonreligious/secular & 13.2 \\
Judaism & 1.3 \\
Islam & 0.5 \\
Buddhism & 0.5 \\
Agnostic & 0.5 \\
Atheist & 0.4 \\
Hinduism & 0.4 \\
Unitarian/Universalist & 0.3 \\
Wiccan/Pafan/Druid & 0.1 \\
Spiritualist & 0.05 \\
Native American Religion & 0.05 \\
\hline
\end{tabular}

Information from Adherents Survey, 2001
Preparation of culturally sustaining teachers (CST) requires an understanding and awareness of the effect of Christian privilege in K-20 classrooms (Brown et al., 2008; Bennett et al., 2015). CST can strive to create a more equitable society and often address cultural factors such as race or sexual orientation, but the "role of spirituality in teaching" is rarely addressed "to challenge power relations" (Tisdell, 2006, p. 19). Christianity, maleness, and Whiteness are perceived as the norm; therefore, invisible advantages exist for Christian individuals similar to White males, whereas nonChristian, non-White and non-male have less power (Blumenfeld, 2006). CST can help challenge cultural and power impediments to equitable education.

Religion is difficult to teach due to complexity and controversy; therefore, religion might be ignored or left out of textbooks and conversations (Marshall, 2006). Teachers might experience discomfort and distress when facilitating contentious issues, such as religion, and possibly resist engaging in discussions with students (Lazar \& Offenberg, 2011). Few studies focus on early childhood classrooms or the teacher's role discussing controversial texts. The authors' previous research exposed this rift, as in-/preservice teachers from diverse religious backgrounds expressed discomfort due to mainstream Christian privilege in public schools or colleges of education even though the United States professes a strict separation of church and state (Gunn et al., 2013; Bennett et al., 2015). These conflicts with prevailing Christian orientation in schools and respondents' personal beliefs strengthened their dedication and commitment to giving back to the community in a way to value diverse beliefs.

White (2009) explored literature on religion and educational research and suggested literacy scholars, pedagogical practice, and multicultural education omitted religion, students' religious backgrounds, and religious literacies. CST is meant to incorporate values, beliefs and perspectives of individuals from different cultural backgrounds, which might include race, religion, linguistics, and socioeconomic status; CST should occur with fluidity and beyond superficial notions (Paris, 2012; Ladson-Billings, 2014). Students' religious backgrounds for in-depth inquiry "holds potential for uncovering unique theoretical and instructional insights that may better support literacy development" (Skerrett, 2013, p. 133).

Knowing the challenges schools and teachers experience, it is essential teacher educators prepare teachers to teach about religion and recognize how their identity, students' identity, and religious background impact teaching and learning (White, 2009). "Culturally sustaining pedagogy seeks to perpetuate and foster-to sustain-linguistic, literate, and cultural pluralism as part of the democratic project of schooling" (Paris, 2012, p. 95). Teacher educators can utilize multicultural literature as a tool to create awareness and understanding of different cultures, challenge assumptions 
and biases, engage in learning, and provide transformative experiences (Gunn et al., 2014/2016; Bennett et al., 2016; Flores et al., 2019; Gunn et al., 2020). Therefore, we explored available children's literature that could provide teachers with a channel to promote discussions about religion in early childhood classrooms.

\section{Children's Literature}

Teachers must adopt CST that helps students learn to be active and empathetic citizens (Gunn \& King, 2015). Banks stated, "Literate citizens in a diverse democratic society should be reflective, moral, and active citizens in an interconnected global world." (Banks, 2004, p. 291). Multicultural education and CST are multi-faceted and complex; we chose to focus on one culturally sustaining literacy practice as a way to discuss religious culture through meaningful, high-quality, impactful children's multicultural literature (Livingston \& Kurkjian, 2005). Teachers not only need strategies to teach all students, but they need to advance their understanding about religious cultures and become aware of literature that offers an approach to discuss religious diversity in a student-friendly manner (Gunn et al., 2013).

Botelho and Rudman (2009) suggested:

Bringing a critical lens to the study of multiculturalism in children's literature invites the reader to deconstruct dominant ideologies of U.S. society (e.g., race, class, gender, and individualism) which privilege those who interests, values, and beliefs are represented by these worldviews. (p. xiv)

Multicultural literature opens conversations about the intersectionality of systems of oppression, such as between race, class, gender or religion (Gunn, 2016). CST and multicultural literature provides the necessary space for children to extend connections beyond text and link to social issues (Paris, 2012; Ladson-Billings, 2014; Bennett et al., 2017). Children's literature can offer helpful examples of religious pluralism and respect for diverse beliefs (Sanders et al., 2010). Through religious children's literature, teachers can facilitate authentic and accurate discussions.

Ayers and Reid (2005) noted teachers should teach: (a) religion as a subject, not a practice, (b) without students attempting to agree or disagree with aspects of different religions, and (c) about a variety of religions, not interpreting one as better or worse. These strategies create deeper understandings of different religions and people who practice the religions. Multicultural literature is a portal to open conversations, a starting place to eliminate prejudice and stereotypes and to develop morals and concepts (Al-Hazza \& Bucher, 2008). Windows and mirrors as a metaphoric image illustrate children require curriculum and books with "mirrors" to affirm their religious identity and importance in school; "windows" offer opportunities to learn about other religions similar and different from ones represented in their community (Bishop, 1990, 2012). CST can encourage windows and mirrors in a safe environment.

Unfortunately, not all children see themselves in children's literature or identify with the characters, and sometimes characters portray negative images and stereotypes (Al-Hazza \& Bucher, 2008). Literature might demonstrate a superficial level of culture or tokenism. It is essential teacher educators selectively choose multicultural literature to challenge teachers' assumptions and biases, demonstrate how to utilize the literature, and illustrate how to change discourse (Flores et al., 2019). This literature should contain students' and classroom peers' culture, while not perpetuating prejudice and stereotypes, and show how worlds are parallel and intersect (Livingston \& Kurkjian, 2005).

Teacher educators must prepare teachers to evaluate multicultural literature to be high quality, authentic, and accurate. Many popular children's books are problematic and lack authenticity. Mendoza and Reese (2001) suggested, "author/ artist Gerald McDermott misrepresents Pueblo social life, religious beliefs, and ceremonial practices" (p.159) in Arrow to the Sun (McDermott, 1977); the Pueblo ceremonial place is misrepresented as a trial place. Teacher educators should provide questions to teachers to evaluate books: (1) does it advance reader's knowledge about culture or religion, (2) is information accurate, (3) does it avoid bias and stereotypes, (4) are components relevant to students' lives, and (5) does it have high quality children's literature characteristics (Gunn et al., 2013). It is imperative teacher educators help teachers identify and utilize quality multicultural literature (Mendoza \& Reese, 2001)

Limited empirical studies exist that examine diverse religious children's literature, especially for early childhood; religion instruction focuses more on middle and high school (Sanders et al., 2010). Although some books might meet high-quality criteria, texts may still contain flaws. Many books may contain archetypes, which could lead to bias. However, children's literature can offer ways to inform students about religions around the world, see the differences and similarities among religions, and support inquiry and conversations.

\section{Conceptual Framework}

Multicultural literacy and CST provided the conceptual framework; we envisioned our research with CST as an understanding that teachers can transform practice and pedagogy to challenge inequities and provide space to affirm students' diverse religious backgrounds. For effective schools, 
we must empower students by connecting curriculum to students' lives, perspectives, and experiences, while offering opportunities to learn about each other (Gay, 2010).

Schools must shift from the perspective of celebratory multiculturalism to critical multiculturalism in order to embrace a CST framework that leads to empowering students as change agents. Teachers need to realize they view their daily lives and interactions through their cultural lenses, which shapes how they understand ideas and ascribe meaning to experiences. Many teachers continue to approach diversity as one-dimensional with limited and generic understandings. They focus on the "other" as a token or engage in a "tourist approach" to multicultural curricula (Evans \& Gunn, 2011; Shuker \& Cherrington, 2016; Bennett et al., 2017). Recognition and celebration of diversity is important, but teachers need to teach further understanding. Cultural awareness begins with knowledge and respect of cultural diversity, and general recognition that different religions have different values.

Multicultural literature offers a lens for students to see 'self' and 'others' and space to enrich in-depth conversations, consequently leading to awareness and deeper understanding of differences such as religion (Gunn et al., 2014/2016; Bennett et al., 2016). According to Banks (1991), a multicultural literacy curriculum is "one that helps students and teachers to know, to care, and to act in ways that develop and cultivate a just society" (p. 135). Students need knowledge, skills, and attitudes to operate in an everchanging world; multicultural literacy allows students to view knowledge from different perspectives, break down assumptions, learn to understand injustices, and take action for change (Banks, 2004; Botelho \& Rudman, 2009).

\section{Purpose}

Our ambition was to explore and select multicultural literature that represents religious diversity for early childhood classrooms, can serve as a tool to empower teachers and their students, and offer space to learn about religions deeply.

\section{Research Design}

\section{Researchers}

Mary Lou, AnnMarie and Susan are considered experts in multicultural children's literature with at least 10 years' experience in teacher education. AnnMarie taught nine years, Susan taught six years, and Mary Lou taught 21 years in elementary schools. Kaya has been an academic Education and Children's Literature librarian for 18 years and is a past Chair of the Association of College and Research Libraries (ACRL), Education and Behavioral Studies Section (EBSS).

\section{Children's Books}

Kaya conducted an extensive search for children's picture books pertaining to religion, followed by multiple stages refining book selection criteria by age level, publication date, prestige (awarded or nominated), and availability.

\section{Selection-Casting a Wide Net}

Initial selection criteria were picture books (1) representing major religions in the U.S., and (2) that had won or been nominated for book awards for 3-8-year-olds. Using 2010 U.S. Census data on self-described religious identification, we selected these religions for consideration: Christianity, Judaism, Islam, Buddhism, Hinduism, Sikhism, Atheism, Agnosticism, Wicca and Native American.

\section{Search Strategy}

Kaya utilized the Children's Literature Comprehensive Database (CLCD), a searchable database listing more than 650,000 reviewed titles "to help teachers, librarians, parents, and childcare providers make appropriate literary choices for children" (CLCD, 2020, para. 4). Title records include metadata on reading level (i.e., grade, age range, and lexile level), genre and fiction/non-fiction category, publication information (date, publisher, language) and indicators of title quality based on 850 children's book award winners and honors books, presence on regional, state, and national best book lists, and professional reviews from sources such as Kirkus, Publishers Weekly, and Children's Literature (http:// www.clcd.com).

Using advanced options, she searched each religion using these database limiters:

- Subject field: Name of religion using Boolean searching for multiple synonymous terms (ie. Christianity, Jesus, bible, or Christ; Jewish, Jew, or Judaism)

- Grade Limit: Infant, Toddler (Age1), Toddler (Age2), PreSchool (Age3), PreSchool (Age4), Kindergarten; 1st, 2nd, 3rd, or 4th Grade

- Category: Fiction or non-Fiction

- Audience: Children and YA only

- Awards and Honors: Winners or Honors

This search was initially conducted in 2018 and then repeated in 2020 to update and include more recent publications. 


\section{Search Results}

This initial search strategy resulted in varied degrees of success for religions: Judaism (233), Christianity (194), Islam (112), Buddhism (25), Hinduism (29), and Native American Religion (32). The same search strategy was inadequate for:

- Wicca: yielded 82 books, but included witches during Halloween, as evil hags, etc. rather than practice/religion;

- Sikhism: 2 found.

- Atheism or agnosticism: 0 found.

Books retrieved drew from ethnic-, racial-, and religious- specific book awards such as: Arab American Book, Christian Book, Asian Pacific American, Hindu Young World-Goodbooks, International Latino Book, Middle East Book, Moonbeam Children's Book, NAACP Image, National Jewish Book, Skipping Stones, and Sydney Taylor Book Awards. The searches recovered children's books that won non-specific ethnically, racially, or religiously specific awards: Caldecott, Carter G. Woodson, Children's and Teen Choice, Children's Illustrated, Eureka! Nonfiction Children's, Governor General's Literary, Orbis Pictus, Cybils, Independent Publisher, Jane Addams Children's, John Newbery Medal, and many more. Some awards, such as Sydney Taylor Book Award, have a long history selecting and promoting high quality children's literature. Yet, other awards, like the Hindu Young World Goodbooks Award, only started in 2016. We opted to expand our results to include nonaward-winning books for religions that did not have a long award history.

\section{Refining Search Results}

Kaya created a spreadsheet with pages for each religion with these categories: Book Title, Author/Illustrator, Publishing Date, Abstract/Review Information, Award, and holdings location. She entered relevant information from each CLCD search into the spreadsheet. Searches frequently retrieved the same book but was only entered it once. Despite search limits by grade, some results included chapter books appropriate to older readers but not entered in spreadsheet. With such dramatic differences in the number retrieved by CLCD searches, Kaya subsequently consulted several booklists and looked up children's books nominated for awards to identify additional books on Sikhism, Buddhism, and Hinduism. During this first stage, she identified and entered a total of 671 books for 2018 and 2020.

For agnosticism and atheism, Kaya revised search terms as keyword only instead of subject heading. This search resulted in 15 books with terms atheism, atheist, agnostic or agnosticism somewhere in the description or more frequently in reviews. Many books listed seemed to be frequent winners of the Cybils Award, a relatively new award by children's/YA book bloggers who target the gap between "too elitist" and "not selective enough" awards.

We narrowed book selections, and Kaya focused only on books that had won an award, been published on or after 2000, and were readily available through InterLibrary Loan (ILL). To determine the location and collect the books, she searched the university's Libraries catalog and obtained books from two of our campuses' libraries and the university's ILL as well as from two surrounding Public Libraries systems using our public library cards.

Table 2 Numbers of books searched, obtained and selected, 2018 and 2020

\begin{tabular}{|c|c|c|c|c|c|c|c|}
\hline Religion & $\begin{array}{l}\text { Search } \\
\text { results } 2018\end{array}$ & $\begin{array}{l}\text { Search } \\
\text { results } 2020\end{array}$ & $\begin{array}{l}\text { Obtained } \\
\text { books } 2018\end{array}$ & $\begin{array}{l}\text { Obtained } \\
\text { books } 2020\end{array}$ & $\begin{array}{l}\text { Selected } \\
\text { books } 2018\end{array}$ & $\begin{array}{l}\text { Selected } \\
\text { books } 2020\end{array}$ & $\begin{array}{l}\text { Selected } \\
\text { books } \\
\text { total }\end{array}$ \\
\hline Buddhism & 23 & 2 & 17 & 2 & 2 & 0 & 2 \\
\hline Christianity & 171 & 23 & 56 & 9 & 3 & 0 & 3 \\
\hline Hinduism & 21 & 8 & 12 & 2 & 1 & 0 & 1 \\
\hline Islam & 87 & 25 & 73 & 11 & 5 & 4 & 9 \\
\hline Judaism & 212 & 21 & 144 & 16 & 17 & 5 & 22 \\
\hline Sikhism & 10 & 2 & 6 & 2 & 0 & 0 & 0 \\
\hline Wicca & 82 & 0 & 11 & 0 & 0 & 0 & 0 \\
\hline Agnosticism/Atheism & 15 & 0 & 15 & 0 & 0 & 0 & 0 \\
\hline Native American Spiritual & 7 & 25 & 7 & 21 & 7 & 5 & 12 \\
\hline Kwanzaa & 7 & 0 & 6 & 0 & 0 & 0 & 0 \\
\hline Minus books retrieved in multiple searches & -79 & 0 & - & 0 & 0 & 0 & 0 \\
\hline Books pertaining to multiple religions & - & 9 & 21 & 5 & 5 & 0 & 5 \\
\hline Total & 556 & 115 & 368 & 68 & 40 & 14 & 54 \\
\hline
\end{tabular}


We were not able to obtain 79 books through either location, and in total, we obtained 436 books (See Table 2).

\section{Rubric}

We designed a rubric to evaluate books that represent religious diversity in children's literature (see Appendix). We explored research that developed an evaluation tool or rubric to examine picture and/or chapter books, in particular pertaining to culture, and used this research to determine criteria to include in our rubric (Pang et al., 1992; Higgins, 2002; Livingston \& Kurkjian, 2005; Al-Hazza \& Bucher, 2008; Gunn et al., 2013; Bennett et al., 2015). Al-Hazza and Bucher (2008) provided a rubric to evaluate children's books about Arabs and Arab Americans in an elementary classroom. Gunn et al. (2013) and Livingston and Kurkjian's (2005) rubrics focused on religious diversity, and Higgins (2002) evaluated children's multicultural books. Bennett et al. (2015) suggested guidelines for selecting literature about children's names and identity; and Pang et al. (1992) recommended guidelines focused on Asian-American children's literature.

AnnMarie and Susan independently read and evaluated each book based on rubric criteria with a rating scale between 1 and 18 for fiction and 1 and 15 for non-fiction. For non-fiction, we removed the criterion related to the plot. We discussed and separated books with a rating of 15 for fiction and 12 for non-fiction. We conferred and analyzed books that received a 4-point discrepancy to increase inter-rater reliability. We removed any book with a total of 14 or less for fiction and 11 or less for non-fiction.

We recognized certain books would not serve as a good book to teach "about" religion or could not be scored with our rubric. Therefore, we excluded:

1. Fables and tales: we were looking for authentic literature that early childhood children could relate to their lives;

2. Chapter books or books outside the preK-3 level;

3. Books about culture, not specifically addressing religion; and

4. Books not written in English.

\section{Findings}

We searched for books early childhood educators could use to offer space for students to identify with characters (mirrors) and develop understandings and awareness of others (windows). From the 436 books obtained, we selected 54 (see Table 2) that matched the criteria for high quality multicultural literature which represents religious diversity and can be used in early childhood classrooms.
The books selected and obtained illustrate a substantial difference and show a limited number of high-quality multicultural literature representing religious diversity. We suggested more than one book for two authors: two for Polacco (Judaism) and three for Mobin-Ubin (Islam). Holocaust books could account for more books about Judaism; however, we only wanted to include settings in the U.S. for relevancy to children's lives. The other variation resulted from many Christian and other religions focusing too much on promoting beliefs, for example, creation stories or fables. Instruction should "neither promote nor denigrate the ideals of faith" (Douglass, 2002, p. 33). The agnostic and atheist books were chapter books and not age appropriate.

We created a website (https://bit.ly/3ebiQOJ), which displays children's literature selected and links to different books based on religion with an image, description, full summaries, publication date, ISBN, awards, and author. It is important to note some books contain more information to teach about religion than others. Shante Keys and the New Year's Peas (Piernas-Davenport, 2007) is an excellent text about different foods for New Year celebrations and only mentions one religious' element, Diwali, but it could start discussions. Whereas, Lailah's Lunchbox: A Ramadan Story (Faruqi \& Lyon, 2015) has an authentic and realistic plot, information about Ramadan, and a teacher respecting beliefs.

We identified the following themes within the books selected: (1) immigration and refugees, (2) holidays, (3) sharing memories and stories, and (4) building understandings and empathy. Some contained more than one theme; a few consisted of more than one religion. Relationships, whether with families, classmates or friends, were exhibited throughout.

\section{Immigration and Refugees}

We recognized several books included stories about immigration and refugees; these books focused on characters who immigrated to or were refugees who relocated to the United States and illuminated windows and mirrors of refugees' and immigrants' struggles and victories. In Feivel's Flying Horses (Hyde, 2010), Feivel earns and saves money to bring his family from Europe to America. This historical fiction text illustrates the sorrow immigrants face during separation from their family, such as Feivel, a Jewish immigrant in the $19^{\text {th }}$ century. Feivel sings Yiddish songs while he creates carousel horses that resemble his family members at Coney Island, contributing Jewish art to American culture. As another example, In The Best Eid Ever (Mobin-Uddin, 2009), Aneesa, the main character, lives in America and misses her family who still reside in Saudi Arabia. She meets two refugee girls and decides to brighten up their holiday, Eid. This book shows how Aneesa finds comfort with her 
grandma and helping the girls, who left their belongings behind when they had to flee their country. These books portray characters in positive ways in which the reader can see relevancy to their own lives or develop a cultural consciousness of others, windows and mirrors. Although this book provides a space for conversation about diverse religious immigrants and refugees, it also corresponds with the holidays' theme, as it offers authentic information about Eid and Hajj, Islamic holiday and pilgrimage.

\section{Holidays}

Numerous books across the different religions include information about various holidays, such as Ramadan, Hannukah, Diwali, Eid, Chaan Raat, and Easter. Some provide more information about holidays than the others. Patricia Polacco writes about more than one holiday or introduces characters from different cultural backgrounds. For example, in Chicken Sunday, Polacco (1998) shares a story of friendship, forgiveness, and relationships across races and religions. Polacco mentions Easter but illustrates characters who are from different cultures: a Russian American girl and two African American brothers. These three main characters want to purchase a hat for the grandmother for Easter, but some misunderstandings occur with the shop owner. They collaborate to make pysanky eggs, and the shop owner realizes his mistake. This book does not teach about Easter but more about the different characters coming together, yet it could be a book to start talking about Easter. In The Only One Club (Naliboff, 2013), Jennifer feels left out because she is Jewish, and her class is making Christmas decorations. The teacher says she can make Jewish decorations, and Jennifer creates The Only One Club. When her friends ask to join the club, she realizes how they each are unique. In A Party in Ramadan (Mobin-Uddin, 2009), Leena is excited about Ramadan but too young to fast every day, so she decides to fast on Fridays. She then faces a decision to do the right thing when she is invited to a party on a Friday. These three books portray characters from diverse religious backgrounds with strong plots related to holidays where readers can identify with the characters and their cultural consciousness.

\section{Building Understandings and Empathy}

Several books build understandings between characters and develop empathy with characters from diverse backgrounds. Some tell a story of children at school who either are teased and bullied or about a teacher who does not understand behaviors due to religion, for example in Lailah's Lunchbox (Faruqui, 2015) and My Name is Bilal (Mobin-Uddin, 2005). Lailah is fasting for Ramadan, and she is unsure her friends or teacher will understand her religious beliefs. Her mother writes a note to explain why she is fasting, but Lailah does not show the teacher the note. She confides in the librarian, who provides the support, understanding, and empathy she needs. Bilal struggles with his Muslim identity as he starts a new school with his sister. He witnesses his sister being bullied, says nothing, and pretends his name is Bill until a teacher shows him the true meaning of his name. The teacher showed him understanding and empathy to become empowered. Through stories, students might develop understandings of individuals who have different religious backgrounds or connect to the characters as these characters struggle with social situations that may be relevant to students' lives.

\section{Sharing Memories and Stories}

Many authors illustrated the importance of sharing memories and stories from generation to generation. Elder family members narrate stories of family, religion, and traditions to younger family members in these books. In Chachaji's Cup (Krishnaswami, 2013), Neel recognizes the symbolism of his uncle's tea cup; it represents stories of a family and a country split, India and Pakistan. Neel listens to his uncle tell stories of his time in the army and Hindu gods and demons while drinking tea. In a Buddhist book, A Path of Stars (O'Brien, 2012), a grandmother, a Cambodian refugee, shares stories with her granddaughter about places of happiness, family, loss, and memory. She tells her granddaughter about the fruits and plants and how her family would look at the stars. She would like to return and see her brother until she receives the phone call that he is gone. Many Native American books combine telling traditional stories about the tribe's beliefs with contemporary characters. Child (2018), based on her experiences, in Bowwow Powwow writes about a young girl who imagines and elaborates her uncle's traditional stories. Windy Girl attends a powwow with her uncle and Itchy Dog, and when she falls asleep, the dancers and drummers turn into dogs. She dreamt of elders, veterans, a drum group, and many dancers; Windy Girl combined her uncle's stories with her experiences. These texts offer readers connections to their lives with the sharing of memories and stories from older generations.

\section{Native American Books}

When examining Native American religious or spirituality books, it is important to note there are many tribes, languages, traditions, and beliefs, and that spiritual stories differ from tribe to tribe (Irwin, 2000). In addition, the ramifications of colonization on indigenous people are extensive; "From the beginning of cultural contact, Native religious practitioners have engaged in a struggle to sustain their authenticity in the face of sustained oppressive cultural denials" (Irwin, 2000, p. 
1). Some Native Americans might follow traditional spiritual practices, some might practice Christianity or even practice both traditional spirituality and Christianity.

Due to the complexity of Native American Religion and our limited expertise of the many tribes, it warrants individual significant space beyond this manuscript, possibly its own study. Although two of us taught on a reservation, we are not experts on over 500 tribes in the U.S. and 5000 groups in the world. To know if these books are authentic, it requires more than just reading the book. Teachers must have knowledge and understanding of the impact of colonization, boarding schools, and missionaries on Native American communities and be prepared to teach about this impact. Eleven of the Native American books obtained were written and/or illustrated by Native Americans. All twelve books obtained seemed authentic and accurate and could be used to teach about Native American spirituality or religion. Teachers must understand the intricacy of Native American religion and spirituality, and we suggest teachers research, read, and thoroughly analyze Native American Children's books, find an expert in Native American religion or spirituality and consult the award, American Indian Youth Literature (Award: https://ailanet.org/activities/ameri can-indian-youth-literature-award/).

\section{Limitations}

We recognize limitations in our research design and rubric. We did not use any procedures to establish validity of the primary data collection instrument, the rubric. We only selected books available through the university and public libraries, which might not include more recent publications that might not have received awards. We obtained fewer books from the second search due to the Coronavirus pandemic. Some books covered religion but were set in other countries, thus beyond the scope of this rubric. We have expertise in children's literature, CSP, and diversity; however, all individuals have biases, and we might have overlooked a perspective of a religion or spirituality.

\section{Discussion}

We discovered an imbalance and limited amount of highquality children's literature about diverse religions to use in early childhood classrooms. However, there might be additional locations where teachers could find multicultural literature representing religious diversity, such as bookstores or the internet, but with a financial cost. Our rubric offers teachers an approach to evaluate any books they find. Continued research is needed about religiously diverse children's literature to find more high-quality books that might stimulate dialogue and interactions in early childhood and colleges of education classrooms (Sanders et al., 2010). Multicultural literature not only facilitates students' comprehension but how they understand the world (Flores et al., 2019). Religious literacies possess social and political implications as students learn about and solve problems in the world and how to be change agents (Noddings, 2008; Skerrett, 2013).

CST supports religious diversity as the tenets of CST include a safe and supportive classroom that holds high expectations, is relevant to students' lives, and utilizes various strategies and instruction to meet students' needs (Paris, 2012; Ladson-Billings, 2014). Religious literacy is vital in classrooms due to the climate of hate crimes, dissonance, and violence against religious differences around the world (Bishop \& Nash, 2007; Sanders, Foyil, \& Graff, 2010). Teachers' lack of knowledge and fear has led to limited attention on religious topics as well as omission from curricula (Skerrett, 2013). Teaching about religious diversity supports and nourishes students' self-respect, religious, and personal identity, contributes to empathy toward other religions, and illustrates different perspectives (Paris, 2012; Skerrett, 2013; Ladson-Billings, 2014).

Teacher education programs must provide resources, such as children's literature as a medium to navigate curricula (White, 2009). Teacher education programs should utilize literature to facilitate teachers' conversations and understandings of how their beliefs, biases and prejudices impact teaching, and "teacher preparation programs need to prepare future teachers to handle religion in the classroom as part of their subject areas and also how to treat the religious identities of students and families equitably" (Marshall, 2006, p.190). Teacher education programs must approach these topics in social studies methods, foundations, and literacy courses. It is imperative, as the U.S. continues to change, that educators have the skills, strategies, and CST to meet the needs of diverse religious population.

Additional research is needed to examine how teachers can lead discussions and interact with students about cultural and religious topics, especially conversations teachers fear and find controversial (Lazar \& Offenberg, 2011). Teacher education programs must also demonstrate and model for pre-/inservice teachers how to facilitate discussions around religious diversity and use and evaluate this multicultural literature. Teacher education programs need to offer more than exposure to diversity and implement more in-depth experiences with multicultural literature and issues that pre-/inservice teachers fear or have only surface-level understandings.

\section{Concluding Thoughts}

We recommended a rubric and small sample of powerful children's literature we believe supports culturally relevant texts to teach factual information about diverse religions in the U.S. 
and fosters understanding and respect for diverse religious and cultural groups. These books can be used as a vehicle for raising children's awareness of religions in our world, create opportunities for students and teachers to learn about world religions, and offer space to explore commonalities and differences among people from a variety of places and religious practices (Gunn et al., 2020). We no longer can ignore difficult, perplexing, or cumbersome topics because of fear or anxiety, as these issues can negatively impact individuals.

\section{Appendix}

Rubric for Evaluating Books that Represent Diverse Religious Content

We developed this rubric based on previous published articles that evaluated children's literature (Pang et al., 1992; Higgins, 2002; Livingston \& Kurkjian, 2005; Al-Hazza \& Bucher, 2008; Gunn et al., 2013; Bennett et al., 2015).

\begin{tabular}{ll}
\hline Criteria & $\begin{array}{l}1-3 ; 1-\text { poor } 2 \text { - meets some of the } \\
\text { criteria } 3 \text { - excellent }\end{array}$
\end{tabular}

Culturally pluralistic theme The book fosters the idea that religion and diversity are an integral asset. Founded upon tenets of social justice and freedom, the book conveys a continuation of cultural traditions (holidays languages and beliefs) as positive. The book portrays relationships between characters from different cultures. The book promotes non- mandatory assimilation.

Positively portrayed char- The book portrays this specific group acters of people as empowered people. The characters accurately define concepts of struggles for justice appropriate to the religion/cultural group. The literature avoids stereotypes associated with this religion.

Setting in US

Authentic illustrations

Strong plot and characterization

\begin{tabular}{ll}
\hline Criteria & $\begin{array}{l}\text { 1-3; 1- poor 2- meets some of the } \\
\text { criteria 3- excellent }\end{array}$ \\
\hline $\begin{array}{l}\text { Reader's cultural conscious- } \\
\text { ness }\end{array}$ & $\begin{array}{l}\text { The story components are relevant to } \\
\text { the reader's own life and have the } \\
\text { power to positively shape his or her } \\
\text { cultural consciousness. }\end{array}$ \\
\hline
\end{tabular}

\section{References}

Adherents (2001). http://www.adherents.com/rel_USA.html\#religions Al-Hazza, T., \& Bucher, K. T. (2008). Building Arab Americans' cultural identity and acceptance with children's literature. The Reading Teacher, 62(3), 210-219.

Ayers, S. J., \& Reid, S. (2005). Teaching about religion in elementary school: The experience of one Texas district. The Social Studies, 14-17.

Banks, J. A. (1991). Multicultural literacy and curriculum reform. Educational Horizons, 69(3), 135-140.

Banks, J. A. (2004). Teaching for social justice, diversity, and citizenship in a global world. The Educational Forum, 68, 289-298.

Bennett, S. V., Gunn, A. A., Gayle-Evans, G., Barrera, E. S., \& Leung, C. (2017). Culturally responsive literacy practices in an early childhood community. Early Childhood Education Journal, 46(2), 241-248. https://doi.org/10.1007/s10643-017-0839-9

Bennett, S. V., Gunn, A. A., \& Leung, C. (2016). Comprehension strategy instruction with literature circles and response journals: Promoting preservice teachers' metacognitive thinking about a multicultural text. Journal of Literacy Practice \& Research, 42(1), 26-33.

Bennett, S. V., Gunn, A. A., \& Morton, M. L. (2015). Four non-Christian educators chronicle challenges in a Christian-centered society. The Qualitative Report, 20(5), 636-656.

Bishop, R. S. (1990). "Mirrors, windows, and sliding glass doors." Perspectives: Choosing and Using Books for the Classroom, 6(3).

Bishop, R. S. (2012). Reflections on the development of African American children's literature. Journal of Children's Literature, 38(2), 5-13.

Bishop, P. A., \& Nash, R. J. (2007). Teaching for religious literacy in public middle schools. Middle School Journal, 38(5), 20-31. https://doi.org/10.1080/00940771.2007.11461599

Blumenfeld, W. J. (2006). Christian privilege and the promotion of "secular" and not-so "secular" mainline Christianity in public schooling and in the larger society. Equity \& Excellence in Education, 39, 195-210.

Botelho, M. J., \& Rudman, M. K. (2009). Critical multicultural analysis of children's literature: Mirrors, windows, and doors. Routledge.

Brown, N., Wiggins, R., \& Secord, D. (2008). "And God sits next to $m e ":$ The role of religion in teacher education programs. Presentation at $7^{\text {th }}$ International Conference on S-Step. Herstmonceux Castle, East Sussex, England.

Child, B. J. (2018). Bowwow powwow. Minnesota Historical Society Press.

Children's Literature Comprehensive Database. (2020). About CLCD. https://www.clcd.com/\#/universal/aboutus

Douglass, S. L. (2002). Teaching about religion. The World in the Classroom, 60(2), 32-36.

Evans, L. S., \& Gunn, A. A. (2011). It's not just the language: Culture as an essential component in preservice teacher education. Journal of Multiculturalism in Education, 7(1).

Faruqi, R. (2015). Lailah's lunchbox: A Ramadan story. Tilbury House Publishers. 
FBI (2017). Uniform crime report: Hate Crime Statistics. https://ucr.fbi. gov/hate-crime/2017/topic-pages/incidents-and-offenses.pdf

Fitchett, P. F., Heafner, T. L., \& Lambert, R. G. (2014). Examining elementary social studies marginalization: A multilevel model. Educational Policy, 28(1), 40-68. https://doi.org/10.1177/0895904812 453998.

Flores, T. T., Vlach, S. K., \& Lammert, C. (2019). The role of children's literature in cultivating preservice teachers as transformative intellectuals: Literature review. Journal of Literacy Research, 5(2), 214-222. https://doi.org/10.1177/1086296X19839181.

Gay, G. (2010). Culturally responsive teaching: Theory, research, and practice. Teachers College Press.

Gunn, A. A. (2016). Teachers moving forward on a cultural self-awareness spectrum: Diverse children, museums, and young adult literature. Multicultural Perspectives, 18(4), 1-7. https://doi.org/10.1080/ 15210960.2016.1228335.

Gunn, A. A., Bennett, S. V., \& Leung, C. (2014/2016). Preservice teachers' "revelations and connections": Fostering deep conversations while reading multicultural literature. Journal of Contemporary Research in Education, 3(1/2), 37-52.

Gunn, A., Bennett, S. V., \& Morton, M. L. (2013). Culturally responsive literacy pedagogy: Using children's literature to discuss topics of religious diversity. Florida Reading Journal., 49(1), 17-24.

Gunn, A. A., Bennett, S. V., \& van Beynen, K. (2020). Talking About Religious Diversity: Using multicultural literature as a tool. Social Studies and the Young Learner, 33(1), 10-16.

Gunn, A. A., \& King, J. (2015). Using empathetic identification as a literacy tool for building culturally responsive teaching with preservice teachers. Teacher Development, 19(2), 1-15.

Higgins, J. J. (2002). Multicultural children's literature: Creating and applying an evaluation tool in response to the needs of urban educators. New Horizons for Learning.

Hyde, H. S. (2010). Feivel's flying horses. Ken-Ben Publishing.

Irwin, L. (2000). Native American spirituality: A critical reader. University of Nebraska Press.

Jacobs, F. (2019). Big think. World economic forum. https://www.wefor um.org/agenda/2019/03/this-is-the-best-and-simplest-world-mapof-religions

Karamouzis, P. (2015). Religious capital in relation to teachers' views of RE. A comparative study in the Greek educational context. British Journal of Religious Education, 37(2), 170-181. https://doi.org/10. 1080/01416200.2014.984585

Krishnaswami, U. (2013). Chachaji's cup. Lee \& Low Books Inc.

Ladson-Billings, G. (2014). Culturally relevant pedagogy 2.0: a.k.a. the remix. Harvard Educational Review, 84(1), 74-84.

Lazar, A. M., \& Offenberg, R. M. (2011). Activists, allies, and racists: Helping teachers address racism through picture books. Journal of Literacy Research, 43(3), 275-313. https://doi.org/10.1177/10862 $96 \times 11413720$

Lipka, M. (2015). A closer look at America's rapidly growing religious 'nones.' FactTank: News in the Numbers. Pew Research Center. https://www.pewresearch.org/fact-tank/2015/05/13/a-closer-lookat-americas-rapidly-growing-religious-nones/

Livingston, N., \& Kurkjian, C. (2005). Circles and celebrations: Learning about other cultures through literature. The Reading Teacher, 58(7), 696-703.

Marshall, J. M. (2006). Nothing new under the sun: A historical overview of religion in U.S. public schools. Equity \& Excellence in Education, 39, 181-194. https://doi.org/10.1080/10665680600792737.

McDermott, G. (1977). Arrow to the sun: A Pueblo Indian tale. Penguin Random House.

Mendoza, J., \& Reese, D. (2001). Examining multicultural picture books for the early childhood classroom: Possibilities and pitfalls. Early Childhood Research \& Practice, 3(2), 155-169.
Mobin-Uddin, A. (2005). My name is Bilaal. Boyds Mills Press.

Mobin-Uddin, A. (2009). A party in Ramadan. Boyds Mills Press.

Naliboff, J. (2013). The only one club. Flashlight Press.

Niemi, P., Kuusisto, A., \& Kallioniemi, A. (2014). Discussing school celebrations from an intercultural perspective - a study in the Finnish context. Intercultural Education, 25(4), 255-268. https://doi.org/ 10.1080/14675986.2014.926143

Noddings, N. (2008). The new outspoken atheism and education. Harvard Educational Review, 78(2), 369-390.

O'Brien, A. S. (2012). A path of stars. Charlesbridge Publishing.

Pang, V. O., Colvin, C., Tran, M., \& Barba, R. H. (1992). Teachers' choices best new children's books. The Reading Teacher, 46(3), 216-224.

Paris, D. (2012). Culturally sustaining pedagogy: A needed change in stance, terminology, and practice. Educational Researcher, 41(3), 93-97. https://doi.org/10.3102/0013189X12441244.

Pew Research Center (2014). Religious landscape survey. https://www. pewforum.org/religious-landscape-study/

PEW Forum (2015). Religious switching: "Nones" make big gains, Catholics experience big losses. https://www.pewforum.org/2015/05/12/ chapter-2-religious-switching-and-intermarriage/

Peyton, M. R., \& Jalongo, M. R. (2008). Make me an instrument of your peace: Honoring religious diversity and modeling respect for faiths through children's literature. Early Childhood Education Journal, 35, 301-303. https://doi.org/10.1007/s10643-007-0231-2

Piernas-Davenport, G. (2007). Shante Keys and the New Year's peas. Weigl Educational Publishers Ltd.

Polacco, P. (1998). Chicken Sunday. Philomel Books.

Rothenberg, P. (2000). Invisible privilege: A memoir about race, class, and gender (feminist ethics). University Press of Kansas.

Sanders, J., Foyil, K., \& Graff, J. M. (2010). Conveying a stance of religious pluralism in children's literature. Children's Literature in Education, 41, 168-188. https://doi.org/10.1007/s10583-010-9102-3

Shuker, M. J., \& Cherrington, S. (2016). Diversity in New Zealand early childhood education: Challenges and opportunities. International Journal of Early Years Education, 24, 1-16. https://doi.org/10.1080/ 09669760.2016 .1155148$.

Skerrett, A. (2013). Religious literacies in a secular literacy classroom. Reading Research Quarterly, 49(2), 233-250.

Subedi, B. (2006). Preservice teachers' beliefs and practices: Religion and religious diversity. Equity \& Excellence in Education, 39, 227-238.

Ter Avest, K. H., \& Wingerden, M. R. (2017). Half a century of Islamic education in Dutch schools. British Journal of Religious Education, 39(3), 293-302. https://doi.org/10.1080/01416200.2015.1128391.

Tisdell, E. J. (2006). Spirituality, cultural identity, and epistemology in culturally responsive teaching in higher education. Multicultural Perspectives, 8(3), 19-25.

U.N. Commission on Human Rights, Rights of persons belonging to national or ethnic, religious and linguistic minorities. 11 April 1996, E/CN.4/RES/1996/20. https://www.refworld.org/docid/3b00f0c94c. html. Accessed 19 March 2019

Vass, G. (2017). Preparing for culturally responsive schooling: Initial teacher educators into the fray. Journal of Teacher Education, 68(5), $451-462$.

White, K. R. (2009). Connecting religion and teacher identity: The unexplored relationship between teachers and religion in public schools. Teaching and Teacher Education, 25, 857-866.

Publisher's Note Springer Nature remains neutral with regard to jurisdictional claims in published maps and institutional affiliations. 